\title{
Hand injuries in foreign labour workers in an Irish university hospital
}

\author{
Thorsten Sattler MD ${ }^{1}$, Dalia Tobbia MD², Michael O'Shaughnessy MD ${ }^{3}$
}

T Sattler, D Tobbia, M O'Shaughnessy. Hand injuries in foreign labour workers in an Irish university hospital. Can J Plast Surg 2009; $17(1): 22-24$.

The present study reports on a new, rapidly growing patient subpopulation presenting with hand injuries to the Department of Plastic Surgery in Cork University Hospital (Ireland). The impact of the 10 new European Union accession states on the trauma workload is examined. The associated growth in expenditure on interpreter services is also examined. Potential risk factors in the foreign workers' new working environment is explored.

Key Words: Hand injuries; Labour workers; New EU accession states; Translator costs

\section{Traumatismes à la main chez des travailleurs étrangers soignés dans un hôpital universitaire irlandais}

La présente étude fait état d'une population émergente de patients, de plus en plus nombreux à consulter pour des traumatismes à la main au service de chirurgie esthétique de l'Hôpital universitaire de Cork, en Irlande. Les auteurs analysent l'impact de l'accession de dix nouveaux états au sein de l'Union Européenne sur la charge de travail en traumatologie. Ils font rapport sur l'augmentation du coût des services d'interprètes et analysent les facteurs de risque potentiels liés aux conditions de travail de la maind'œuvre étrangère.
$\mathrm{O}$ May 1, 2004, 10 countries (Cyprus, Czech Republic, Estonia, Hungary, Latvia, Lithuania, Malta, Poland, Slovakia and Slovenia) joined the European Union (EU). Following this, the total immigration flow into Ireland in the 12 months from May 2004 to April 2005 is estimated to be 70,000 - a record high since the annual migration estimates began in 1987. Over one-third (38\%) of all immigrants were nationals of the 10 new EU accession states, mostly from Poland and Lithuania (1).

In the fourth quarter of 2005, there were 65,000 immigrants from the new accession states working in Ireland, which constitutes $36 \%$ of all non-nationals in the Irish labour force. In 2003, those 10 countries contributed only $8 \%$ to the non-Irish labour force (2).

The present study focussed on this new, rapidly growing patient subpopulation presenting with hand injuries to the Department of Plastic Surgery in Cork University Hospital (Ireland) from 2000 to 2005.

\section{PATIENTS AND METHODS}

The present study is registered and approved by the Cork University Hospital Quality Unit. All hand injuries presenting to the Department of Plastic Surgery from July to December 2005 were analysed and compared with hand injuries treated in the department within the previous five years. Of special interest were patients from the 10 countries that joined the $\mathrm{EU}$ on the May 1, 2004. Computer data, patient charts and operation records were used to extract the following data:

- nationality;

- nature and place of injury;
- age, sex, dexterity, occupation and smoking habits;

- line of management undertaken;

- patient compliance and follow-up;

- English proficiency/need for interpreter services; and

- type of health insurance.

All data extracted were computerised on FileMaker Pro 7 (FileMaker Inc, United Kingdom), classified and tabled.

\section{RESULTS}

Progression of patient numbers

Over the past six years, the total number of patients with hand injuries presenting to the Department of Plastic Surgery remained relatively stable, ranging from 798 in 2000 to 762 in 2005 (Table 1).

On examining the number of patients originating from the 10 new EU accession states, major changes can be noticed. In 2000, not a single patient from the EU group presented to the hand service.

Comparing 2003 with 2004, the patient numbers of the EU group more than doubled from $18(2.4 \%)$ to $41(4.9 \%)$ in absolute and relative figures. This trend continued in 2005 when the patient number jumped to 71 (9.3\%) (Table 1).

Demographic data and pattern of injury of the EU group in 2005

From July to December 2005, a total of 762 patients presented to our service with hand injuries; $71(9.3 \%)$ of these were from the ten new EU accession states (Table 1). In this subgroup, there were 67 men (94\%) and four women (6\%), and the mean age was 36 years. Forty-eight patients $(68 \%)$ were smokers.

${ }^{1}$ Department of Plastic and Hand Surgery, University Medical Centre, Freiburg, Germany; ${ }^{2}$ Division of Plastic Surgery, University of Toronto, Sunnybrook Health Sciences Centre, Toronto, Ontario; ${ }^{3}$ Department of Plastic, Hand and Reconstructive Surgery, Cork University Hospital, Wilton, Cork, Ireland

Correspondence: Dr Thorsten Sattler, Tennenbacherstr 50A, Freiburg, Germany 79106. Telephone 49-0170-5800352,

fax 49-0761-2702501, e-mail thorstensattler@hotmail.com 
TABLE 1

Progressive increase of patients from 10 new European Union (EU) accession states* presenting with hand injuries to Cork University Hospital (2000 to 2005)

\begin{tabular}{lcc}
\hline Year (July-December) & $\begin{array}{c}\text { Total number of } \\
\text { patients with } \\
\text { hand injuries }\end{array}$ & $\begin{array}{c}\text { Number (\%) of patients } \\
\text { with hand injuriesfrom } \\
\text { the new EU countries }\end{array}$ \\
\hline 2005 & 762 & $71(9.3)$ \\
2004 & 839 & $41(4.9)$ \\
2003 & 757 & $18(2.4)$ \\
2002 & 792 & $5(0.6)$ \\
2001 & 783 & $2(0.3)$ \\
2000 & 798 & $0(0)$ \\
\hline
\end{tabular}

*Cyprus, Czech Republic, Estonia, Hungary, Latvia, Lithuania, Malta, Poland, Slovakia and Slovenia joined the EU May 1, 2004

\section{TABLE 2}

Place of injury (71 patients)

\begin{tabular}{lc}
\hline Place of injury & $\mathbf{n}(\%)$ \\
\hline At work & $62(87)$ \\
Leisure activity & $6(9)$ \\
At home & $3(4)$ \\
\hline
\end{tabular}

With regard to the place of injury, 62 patients (87\%) sustained their injuries at work, three at home (4\%) and six (9\%) during leisure activity (Table 2).

The majority of the patients were construction workers $(52 \%)$. The remainder were factory workers $(20 \%)$, farm workers $(11 \%)$, butchers $(7 \%)$ and carpenters $(7 \%)$. One was a student and one patient was unemployed (Table 3).

Thirty-five injuries affected the dominant hand (49\%). Fifty-six patients $(79 \%)$ presented with simple hand injuries and 15 (21\%) with complex hand injuries. Postoperatively, 20 patients (28\%) returned to their home country. Ten of those had complex hand injuries. With regard to compliance, 29 of 71 patients (41\%) failed to attend the outpatient clinic for followup. None of the 71 patients had health insurance in Ireland.z

\section{Progression of translator costs}

At the same time as the number of patients from the 10 new EU accession states presenting for treatment at the Department of Plastic Surgery increased, there was a corresponding increase in the cost for translator services. In 2000, $€ 5,874$ were spent on interpreters. This figure multiplied by a factor of six in 2004, when $€ 29,099$ were spent on translator services. This figure rose by another $50 \%$ in 2005 , when $€ 44,410$ were spent on translators (Table 4).

\section{DISCUSSION}

When Cyprus, Czech Republic, Estonia, Hungary, Latvia, Lithuania, Malta, Poland, Slovakia and Slovenia joined the EU on May 1, 2004, the flow of 70,0000 immigrants into Ireland over the following 12 months was the highest ever recorded since migration estimates began in 1987 (1). Over one-third of all immigrants (38\%) were nationals of the 10 new EU accession states (1). They are the fastest growing group within the non-Irish labour force, increasing from just under 30,000 in the last quarter of 2004 to over $65,000(36 \%)$ in the last quarter of 2005 (2).
TABLE 3

Patient occupation $(n=71)$

\begin{tabular}{lc}
\hline Occupation & $\mathbf{n}(\%)$ \\
\hline Construction worker & $37(52)$ \\
Factory worker & $14(20)$ \\
Farmer & $8(11)$ \\
Butcher & $5(7)$ \\
Carpenter & $5(7)$ \\
Student & $1(1)$ \\
Unemployed & $1(1)$ \\
\hline
\end{tabular}

TABLE 4

Progression of translator costs for patients from 10 new European Union (EU) accession states* presenting with hand injuries to Cork University Hospital (2000 to 2005)

\begin{tabular}{lc}
\hline Year (January - December) & Translator costs (in Euros) \\
\hline 2005 & 44,410 \\
2004 & 29,099 \\
2003 & 30,507 \\
2002 & 19,277 \\
2001 & 9,284 \\
2000 & 5,874
\end{tabular}

*Cyprus, Czech Republic, Estonia, Hungary, Latvia, Lithuania, Malta, Poland, Slovakia and Slovenia joined the EU May 1, 2004

This migration process has not only had an impact on the Irish economy, but as our study shows, has also placed a significant burden of care on the Irish health care system. Since 2000, the total number of patients with hand injuries presenting to our services remained relatively stable, whereas the number of patients originating from the 10 new EU accession states increased dramatically over the past six years. From July to December 2000, not a single patient of the group in question presented to our hand services. In contrast, this number jumped to $71(9.3 \%)$ in the period from July to December 2005.

Employment in the construction industry continued to grow strongly in 2005 , with 25,800 new construction workers employed. In the fourth quarter of 2005 , foreign nationals accounted for $10 \%$ of both the construction and production industry sector (2).

These figures were reflected in the patient population we focussed on. Almost three-quarters were construction workers (52\%) and factory workers (20\%). Most of the other patients were also employed in accident-prone sectors (farming, the meat trade, carpentry). Because almost nine of 10 patients sustained their injuries at work, the question must be asked as to whether there are potentially increased risk factors operating in the foreign workers' new working environment. The relative risk of a hand injury is increased when working with equipment operated in a different manner, using a different work method to do the task, doing an unusual task or doing a task under a significant time constraint (3). In our patient population, there was at least one risk factor present for most individuals. Many performed tasks that they did not perform in their home countries, or performed differently. Because proficiency in the English language was limited in most patients, it is unlikely that job descriptions and safety regulations were fully understood. With safety training, protection gear, correct job allocation and job 
experience, the incidence of occupational acute hand injuries can be reduced (3). It is important, therefore, that these workers are trained to use machinery and equipment properly and that their workers rights are acknowledged.

Only one of the 71 patients was unemployed. This young, predominantly male, patient group must be considered highly motivated to work, because in the fourth quarter of 2005 the seasonally adjusted overall unemployment rate in Ireland was $4.4 \%$.

In addition, our focus group proved to be a difficult patient population with regard to their compliance. Postoperatively, more than one-quarter returned to their home countries and were lost to follow-up. Fifty per cent of these patients had complex hand injuries. This is problematic, because patients with more serious hand injuries are more likely to have significant long-term impairment of hand function (4). The reasons to leave Ireland varied. Some patients did not get paid sick leave and felt that the cost of living was lower in their home country. Others hoped to have better health insurance coverage in their home country because they did not have any health insurance in Ireland (none of the 71 patients of our focus group had health insurance in Ireland).

With regard to compliance, two of five failed to attend our outpatient clinic for follow-up. This is a disappointing figure, taking into account that more time was spent in the clinic and on ward level especially on patients with limited English. In some cases, interpreting services were used on several occasions (on initial contact in the clinic, preoperatively to get informed consent, postoperatively, before discharge, etc).

The increased use of interpreting services is reflected in increased expenditure on translators in Cork University Hospital. Whereas in 2000 , less than $€ 6,000$ were spent on interpreters, this figure rose to nearly $€ 45,000$ in 2005 . This equates to an increase of $750 \%$ within a six-year period. Like other authors, we believe that this expenditure is necessary for patient safety and a good functional outcome, because language barriers and nonprofessional ad hoc interpretations can have potentially negative clinical consequences $(5,6)$.

\section{CONCLUSION}

We have seen a new, fast-growing patient population presenting with hand injuries at the Department of Plastic Surgery in Cork University Hospital. This predominantly young and male non-Irish labour force is highly motivated to work but has very limited knowledge of the English language, which most likely puts them at increased risk of injury at the workplace and also makes the treatment of their injury more difficult because of communication difficulties. In addition, compliance is an issue and would appear to be mainly due to being under huge pressure to return to work as soon as possible, or the need to return to their country of origin. Interpreter services are vital for safe and effective treatment of their injuries. Furthermore, it is important that these workers get trained on their job and that their workers rights are acknowledged.

\section{REFERENCES}

1. Central Statistics Office, Ireland. Population and Migration Estimates, Ref 163/2005, ISSN 1393-5593, 2005:1-9.

2. Central Statistics Office, Ireland. Quarterly National Household Survey, Ref 28/2006, ISSN 1393-6875, 2006:1-31.

3. Sorock GS, Lombardi DA, Hauser R, et al. A case-crossover study of transient risk factors for occupational acute hand injury. Occup Environ Med 2004;61:305-11.

4. Hung LK, Ho KK, Leung PC. Impairment of hand function and loss of earning capacity after occupational hand injury: Prospective cohort study. Hong Kong Med J 1999;5:245-50.

5. Flores G, Barton Laws M, Mayo SJ, et al. Errors in medical interpretation and their potential clinical consequences in pediatric encounters. Pediatrics 2003;111:6-14.

6. Jacobs EA, Shepard DS, Suaya JA, et al. Overcoming language barriers in health care: Costs and benefits of interpreter services. Am J Public Health 2004;94:866-9. 